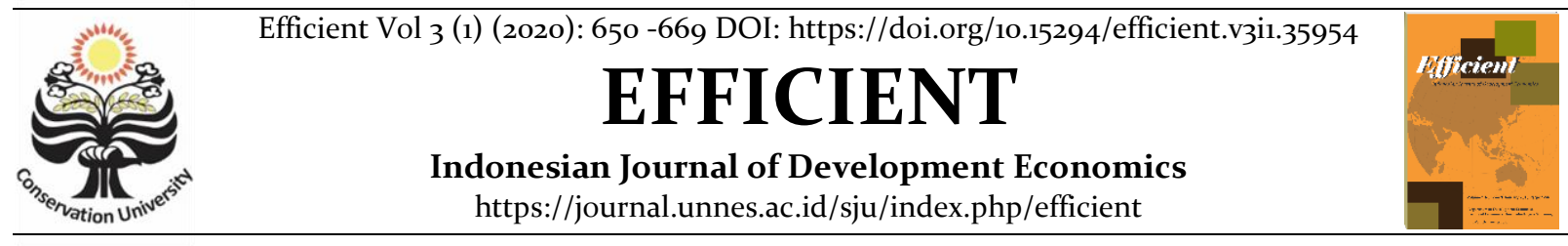

\title{
Implementation of Swadaya Housing Stimulant Assistance
}

\author{
Mia Sekarvilia ${ }^{1 凶}$, Karsinah $^{2}$ \\ Jurusan Ekonomi Pembangunan, Fakultas Ekonomi, Universitas Negeri Semarang
}

Permalink/DOI: https://doi.org/10.15294/efficient.v3i1.35954

Received: July 2019 ; Accepted: October 2019 ; Published: January 2020

\begin{abstract}
People who are less fortunate still find it difficult to get access to decent homes. The Government of Indonesia through the Ministry of Public Works and Housing has developed a program that is oriented towards housing development, namely the Self-Help Housing Stimulant Assistance aimed at Low-Income Communities. The purpose of this study is to measure the success of the implementation of Self-Help Housing Stimulant Assistance in Tempuran Village, Bringin District, Semarang Regency. The research method used is descriptive percentage. The type of data used is primary data using a questionnaire. The variables used are program standards and targets, institutional capacity, funding and social and political conditions. The results of the study, the percentage of standard variables and program targets is $73 \%$ categorized as successful. The results of the analysis of the percentage of institutional capacity variables that is $73 \%$ are categorized successful. The results of the analysis of the percentage of financing variables are $86 \%$ until the categorization is very successful. The results of the analysis of the percentage of social and political conditions variables are $44 \%$ categorized quite successful. The policy implications, assistance and supervision of the Field Facilitator are needed for the KPB to carry out its development independently, the need for prior notification of the preparation of additional self-funding in the BSPS program by the beneficiary community itself for the completion of the housing construction process, the need for participation from surrounding communities and interest groups who have the opinion that the implementation goes well
\end{abstract}

Keywords: Minimum Wages, Economic Growth, Industry, Unemployment

\begin{abstract}
Abstrak
Masyarakat yang kurang beruntung masih sulitnya akses untuk mendapatkan rumah layak huni. Pemerintah Indonesia melalui Kementeriann PUPR membuat suatu program yang berorientasi pada pembangunan perumahan yaitu Bantuan Stimulan Perumahan Swadaya ditujukan bagi Masyarakat Berpenghasilan Rendah. Tujuajn penelitian ini adalah untuk mengukur keberhasilan impelementasi Bantuan Stimulan Perumahan Swadaya di Desa Tempuran Kecamatan Bringin Kabupaten Semarang. Metode penelitian yang digunakan adalah deskriptif persentase. Jenis data yang digunakan adalaah data primer dengan menggunakan kuesioner. Variabel yang digunakan adalah standar dan sasaran program, kapasitas kelembagaan, pembiayaan serta kondisi sosial dan politik. Hasil penelitian persentase variabel standar dan sasaran program adalah sebesar $73 \%$ dikategorikan berhasil. Hasil analisis persentase variabel kapasitas kelembagaan yaitu 73\% dikategorikan berhasil. Hasil analisis persentase variabel pembiayaan adalah $86 \%$ sdikategorikan sangat berhasil. Hasil analisi persentase variabel kondisi sosial dan politik adalah $44 \%$ dikategorikan cukup berhasil. Implikasi kebijakan, pendampingan dan pengawasan dari Tenaga Fasilitator Lapangan diperlukan agar KPB melakukan pembangunannya secara swadaya, perlunya pemberitahuan terlebih dahulu untuk persiapan dana tambahan swadaya pada program BSPS oleh masyarakat penerima bantuan itu sendiri demi terselesaikannya proses pembangunan rumah, perlunya partisipasi dari masyarakat sekitar serta kelompok kepentingan yang berpengarung agar implementasi berjalan dengan baik
\end{abstract}

Kata Kunci: Upah Minimum, Pertumbuhan Ekonomi,Industri, Pengangguran

How to Cite: Sekarvilia, M., \& Karsinah, K. (2020). Implementation of Swadaya Housing Stimulant Assistance. Efficient: Indonesian Journal of Development Economics, 3(1), 650-669. https://doi.org/10.15294/efficient.v3i1.35954

(c) 2019 Semarang State University. All rights reserved

\footnotetext{
Alamat Korespondensi :

Alamat: Gedung L2 Lantai 2 FE Unnes

Kampus Sekaran, Gunungpati, Semarang, 50229

E-mail : Sekarmia@gmail.com
}

ISSN 2655-6197 


\section{INTRODUCTION}

Poverty is one of the complex problems that is almost experienced by all regions in Indonesia, one of which is Central Java. Poverty is a condition or condition of a person's inability to fulfill his basic needs such as clothing, food, housing, education and health, which is caused by the scarcity of means to fulfill needs or the difficulty of accessing education and health. Poverty causes unable to meet the basic needs of life, so that his life is not prosperous. The level of community welfare in an area basically can be seen in plain view of the existence and ownership of his house. (BPS 2018).

The house is one of the basic needs of individuals. But for some disadvantaged people, it is still difficult to access to get a decent home. Low income earners per month are below the requirements to get housing ownership credit from the National Savings Bank, the results of the development of public housing companies and especially development companies that cannot be reached by low income people are forced to increase the occupants of houses or make patchwork on their homes. This causes a decrease in the quality of housing that is inhabited by most low-income people.

Regional development is carried out to increase the distribution of national development in all regions. (Berliana and Praise 2017). The Government of Indonesia through the Ministry of Public Works and
Public Housing developed a program oriented to housing development, namely the Self-Help Housing Stimulant Assistance aimed at LowIncome Communities and regulated by the Republic of Indonesia Minister of Public Works and Public Housing Regulation No. 07 / PRT / M / 2018. This program is carried out to support the acceleration of housing development in increasing access to housing. Self-help Stimulant Assistance, abbreviated as BSPS, is a government assistance for lowincome people to encourage and increase selfsufficiency in improving the quality of housing and new construction along with infrastructure, facilities and public utilities.

There are still various kinds of problems and discrepancies in the application of BSPS including those based on research from Isabela, Sesar and Amaliatulwalidain (2014) in Mulyo Rejo Village, Way Serdang District, Mesuji Regency, there are problems regarding the adequacy of BSPS funds due to lack of understanding of the beneficiary community that the assistance received is only of a nature stimulants and a decline in aid funding and a lack of human resources. Then the research conducted by Zukarnain (2016) in the implementation of BSPS in South Parigi Subdistrict also has problems including those who are not wise in the use of aid which should fund only for renovations but used for new development so that construction is not completed, then there are budget cuts which is not explained in its designation and the late distribution of building materials. Research 
conducted by Inggriani (2015) in the Dharmasraya Regency in implementing BSPS there was a problem of lack of communicants and information so that many people were unaware of the BSPS program and the recipient community of BSPS also did not understand the BSPS funds which were stimulant, then the lack of human resources also became an obstacle in implementing BSPS.

Semarang Regency as the second most recipient of BSPS as a place of research. The number of RTLH in Semarang District based on 2015 PDBT data was 37,437, and Bringin District with the highest number of uninhabitable houses (RTLH) being the largest recipient in Semarang Regency.

Tempuran village as the recipient of the most BSPS Programs in Bringin District in 2018 is 58 units. Bringin Subdistrict consists of 16 villages, 5 other villages that have not had the opportunity to get assistance, namely Gododalem Village, Nyemoh Village, Popongan Village, Truko Village and Wiru Village. The unequal reception of BSPS means the unequal rights of people living in RTLH conditions to own and occupy a decent house in Semarang Regency.

Based on the initial observation interview to the beneficiary (Mr. Kumarudin, one of the KPB chairmen in Tempuran Village) on February 16, 2019 there was a BSPS implementation in Tempuran Village that was not in accordance with the provisions including

Tabel 1.Penerima BSPS PK di Kecamatan Bringin Tahun 2018

\begin{tabular}{lll}
\hline No & Village & Amoont (unit) \\
\hline 1 & Tempuran & 58 \\
2 & Kalijambe & 53 \\
3 & Bringin & 53 \\
4 & Pakisarum & 51 \\
5 & Rembes & 50 \\
6 & Sendang & 50 \\
7 & Banding & 47 \\
8 & Kalikurmo & 45 \\
9 & Lebak & 31 \\
10 & Sambirejo & 30 \\
11 & Tanjung & 21 \\
\multicolumn{7}{l}{ Total } & 489
\end{tabular}

Source: Dinas Pemberdayaan Masyarakat dan Desa Kabupaten Semarang

"Most of the recipients here are doing their own construction, not in groups, because they don't have the time either, looking for individual craftsmen some are building new houses too (Penerima disini kebanyakan melakukan pembangunannya sendiri-sendiri, tidak berkelompok, karena tidak sempat juga, pada cari tukang sendiri-sendiri... ada yang bangun rumah baru juga"

Based on the statement of $\mathrm{Mr}$. Kumarudin, the beneficiary community formed in the group of aid recipients did not carry out the construction in groups, then there were people who built new houses, whereas in the provision of BSPS assistance this was only a stimulant so that the allotment for repair or improvement of the quality of the 
house if used for the construction of new houses means that the assistance obtained is not enough, and there are no sanctions for the recipient community who do not carry out the construction according to the provisions.

Implementation is one of the stages in the policy process. The implementation process becomes important, because the successful implementation of a policy program will have an impact in accordance with the objectives of the program made. Based on research conducted by Wardani (2010) the success of implementation is influenced by several things including standards and policy objectives, institutional capacity, and financing.

The suitability of program implementation in accordance with the standards and targets specified in the technical guidelines and regulations can affect the success of program implementation, this is because in a program there are already limits and program provisions as well as clear program implementation objectives. Based on research conducted by Zulkarnain (2016) that the performance of policy implementation can be measured in terms of success if the basic measures and policy objectives must be seen to be understood well by the implementers of the policy and the people who are the target group. The appropriateness of the organizing process and the duties and responsibilities carried out by the implementor become part of the institutional capacity measure. The attitude and ability of the human resources involved as the program implementation influences the successful implementation of the program. Based on research conducted by Inggriani (2015) that the role and attitude of HR as an implementor are things that support the smooth implementation of the program. Then in his research Priadi (2018) the relationship between institutions and the attitude of the implementor is a matter of influencing program implementation.

One of the resources used besides HR is financing or funding. Program funding in implementation and the adequacy of resources channeled can affect the success of program implementation. Based on Juniarko's research, Surjono and Anwar (2012) Program funding affects the smooth implementation of the program, both from the mechanism of aid distribution and the form of aid distributed. Then the research conducted by Isabela, Sesar and Amaliatulwalidain (2017) community understanding of the assistance received affects the adequacy of assistance according to program needs.

Social and political conditions are also important in influencing implementation. Social and political conditions in each place are different so that it could be that the implementation is said to be successful in one place but not in other places due to different conditions. Based on research conducted by Nata, Manossoh and Mawikere (2018) that the participation of local communities and village officials is important to support the running of the program. Then the research conducted by Hariyani (2016) characteristics of the institutions and ruling regimes influences the implementation of the program. The purpose of this study was to measure the successful implementation of the Self-Help Housing Stimulant Assistance Program in Tempuran Village, Bringin District, Semarang Regency.

\section{METHOD}

This research uses descriptive quantitative method. According to Sugiyono 
(2014) quantitative research methods are research in which data are in the form of numbers and analysis using statistics. Researchers used this method to describe the success rate of the implementation of the SelfHelp Housing Stimulant Assistance Program in Tempuran Village, Bringin District, Semarang Regency.

This study uses primary data that is data obtained directly through research informants. Data obtained through questionnaires, and documentation. The primary data source in this study came from a questionnaire with samples taken from the beneficiary community in Tempuran Village. Measuring success indicators used were: program standards and targets, institutional capacity, funding, and social and political conditions

In the technique of determining the sample for the questionnaire used a random sampling technique. To get the sample, Slovin formula is used in the determination as follows, from the total population with an inaccuracy rate of $12 \%$, then using the formula above obtained a sample of:

$$
\begin{aligned}
& n=\frac{58}{1+58 .(0.12)^{2}} \\
& n=\approx 32
\end{aligned}
$$

Then the sample taken for filling out the questionnaire was 32 residents receiving BSPS in Tempuran Village

The technique of calculating the questionnaire uses the Guttman scale, where the respondent chooses a firm answer from two answer choices namely yes and no or already and not yet. The technique of scoring on the questionnaire by
Sugiyono (2014) applied in this study is as follows:

For answers "Yes" or "Already" given a score of 1 and For answers "No" or "Not yet" given a score of $\mathrm{o}$

Questionnaire result data was calculated by percentage descriptive analysis. Then transform from each variable into a sentence. The calculation results are included in the percentage table according to the application criteria. How to determine the application criteria is to determine the highest and lowest percentage first using the following formula Sahara, et al (2012):

highest percentage

$=\frac{\sum \text { item } \times \sum \text { respondent } \times \sum \text { highest score }}{\sum \text { item } \times \sum \text { respondent } \times \sum \text { highest score }}$

$\times 100 \%$

lowest percentage $=$

$\frac{\sum \text { item } \times \sum \text { respondent } \times \sum \text { lowest score }}{\sum \text { item } \times \sum \text { respondent } \times \sum \text { highest score }} \times 100 \%$...... (2)

After obtaining the highest and lowest percentage the next step is to determine the class interval with the formula Sahara, et al (2012):

$$
\text { class } \text { interval }=\frac{\% \text { the highest }-\% \text { Lowest }}{\text { the desired class }} \text {..........(3) }
$$

This study uses 5 classes namely; Very Unsuccessful, Not Successful, Quite Successful, Successful, and Very Successful. How to calculate descriptive percentages based on the scores received namely;

$$
D P=\frac{n}{N} \times 100 \%
$$


Keterangan:

$\mathrm{DP}=$ Descriptive percentage

$\mathrm{n}=$ Empirical Score (score obtained)

$\mathrm{N}=$ Ideal score for each question item

Based on the calculation results, the following criteria are made:

Tabel 2. Kriteria No Persentage Criteria

\begin{tabular}{lll}
\hline No & Persentage & Criteria \\
\hline 1 & $81 \%-100 \%$ & Very successful \\
2 & $61 \%-<80 \%$ & Was successful \\
3 & $41 \%-<60 \%$ & Successful enough \\
4 & $21 \%-<40 \%$ & Not successful \\
5 & $0 \%-<20 \%$ & Very unsuccessful \\
\hline
\end{tabular}

\section{RESULTS AND DISCUSSION}

In 2018 Tempuran Village received a SelfHelp Housing Stimulant Assistance (BSPS) with 58 beneficiaries in four hamlets namely Cekelan, Krajan, Glompong and Tepusan. The acceptance of the BSPS is mandated by the central government for low-income people to improve the quality of houses that were previously unfit for habitation and by selfsupporting development by the community. Regulations and technical instructions that have been made and issued by the central government in the form of ministerial regulations as well as technical implementation instructions which can then be used as references or guidelines for implementors in implementing BSPS programs

The implementation of the Self-Help Housing Stimulant Assistance Program in Tempuran Village was measured based on 4 variables, namely the program's standards and targets, institutional capacity, financing and social and political conditions. The percentage is divided into 5 classes the lowest percentage is 0 and the highest is $100 \%$ with intervals of each class is $20 \%$, namely by category, very unsuccessful, unsuccessful, moderately successful, successful, and very successful. The results of this research are said to be successful with a percentage of $71 \%$ calculated based on the acquisition of questionnaire scores that have been filled out by respondents. The results and discussion of the percentage acquisition of each variable are as follows:

\section{Program Standards and Targets}

There are 2 indicators measuring the success of implementation in the standard variables and program targets, namely the suitability of the program recipient and the condition of the house before and after the program.Hasil analisi persentase kesesuian penerima program adalah sebagai berikut:

Based on the percentage results that $100 \%$ or all respondents have their own homes and also have land certificates so that renovated houses will not have problems in terms of ownership or land disputes. All recipients are also the first time receiving housing assistance. All beneficiaries also formed a group of recipients of aid (KPB), this group was a non-governmental group and within the group also formed a chairperson, secretary and treasurer who were concurrently members of the group, the purpose of establishing a KPB was to increase community self-sufficiency in order to improve housing quality. However, groups consisting of less than 20 people according to the provisions in 1 group. So the percentage for indicators of suitability of program recipients is $80 \%$. 
Table 3. Analysis Results of Percentage of Program Beneficiaries' Conformity

\begin{tabular}{|c|c|c|c|c|}
\hline No & Question & $\begin{array}{l}\text { Number of } \\
\text { Respondents }\end{array}$ & $\begin{array}{l}\text { Result } \\
\text { Score }\end{array}$ & Persentage \\
\hline 1 & $\begin{array}{l}\text { Occupies the only house that belongs to } \\
\text { yourself }\end{array}$ & 32 & 32 & $100 \%$ \\
\hline 2 & $\begin{array}{l}\text { Having a land certificate / so that the land is } \\
\text { not in dispute }\end{array}$ & 32 & 32 & $100 \%$ \\
\hline 3 & First time receiving housing assistance & 32 & 32 & $100 \%$ \\
\hline 4 & Form beneficiary groups & 32 & 32 & $100 \%$ \\
\hline 5 & The group consists of 20 people & 32 & o & o\% \\
\hline \multicolumn{2}{|r|}{ Maximum scores, total score and percentage score } & 160 & 128 & $80 \%$ \\
\hline
\end{tabular}

Source: processed data

The results of the analysis of the of the roof truss or roof cover, that is all suitability of housing conditions before the respondents with mildly damaged or heavily program are as follows Based on the damaged conditions that are $100 \%$ experienced percentage calculation, the most damage to by all respondents. the building is on the roof of the building part

Table 4. Results of Analysis of Percentage of Housing Conditions Before the Program

\begin{tabular}{|c|c|c|c|c|}
\hline \multirow{2}{*}{ No } & \multirow{2}{*}{ Questiom } & \multirow{2}{*}{$\begin{array}{l}\text { Number of } \\
\text { Respondent }\end{array}$} & \multicolumn{2}{|l|}{ Result } \\
\hline & & & Score & Persentage \\
\hline 1 & $\begin{array}{l}\text { The condition of the top (roof) of the building is } \\
\text { damaged }\end{array}$ & 32 & 32 & $100 \%$ \\
\hline 2 & $\begin{array}{l}\text { The condition of the building walls in a damaged } \\
\text { state }\end{array}$ & 32 & 31 & $97 \%$ \\
\hline 3 & $\begin{array}{l}\text { The condition of the bottom of the building } \\
\text { (floor) is damaged }\end{array}$ & 32 & 21 & $66 \%$ \\
\hline 4 & Insufficient external lighting from inside & 32 & 27 & $84 \%$ \\
\hline 5 & Insufficient ventilation in the house & 32 & 19 & $59 \%$ \\
\hline 6 & Don't have your own latrine & 32 & 4 & $13 \%$ \\
\hline 7 & Do not have their own bathroom & 32 & 4 & $13 \%$ \\
\hline 8 & Don't have your own bedroom & 32 & 2 & $6 \%$ \\
\hline 9 & on't have your own living room & 32 & 6 & $19 \%$ \\
\hline 10 & Building area is not enough space & 32 & 7 & $22 \%$ \\
\hline \multicolumn{2}{|r|}{ Maximum of scores, total score and percentage score } & 32 & 153 & $48 \%$ \\
\hline
\end{tabular}

Source: processed data 
Then out of a total of 32 respondents $66 \%$ or 21 respondents have building floors that are still ground and $97 \%$ or 31 respondents have buildings with wooden walls. $84 \%$ or 27 of a total of 32 respondents had poor lighting conditions and $59 \%$ or 19 of a total of 32 respondents ventilated for ventilation in the house were still not enough. Some people also do not have a toilet or bathroom of their own, but the percentage can be seen only $13 \%$ or only 4 people from a number of 32 respondents $87 \%$ or 28 others have their own toilet and bathroom, meaning that most of the community already has a toilet and own bathroom. Of the minimum area adequacy of $22 \%$ or 7 recipients whose houses do not meet the minimum adequacy of the area and 25 other recipients have met the minimum adequacy of area. The percentage of housing conditions before the program is $48 \%$ with unfit living conditions

The results of the analysis of the percentage of housing conditions after the program are as follows:

Table 5. Results of Analysis of Percentage of House Conditions After the Program

\begin{tabular}{|c|c|c|c|c|}
\hline \multirow{2}{*}{ No } & \multirow{2}{*}{ Questioan } & \multirow{2}{*}{$\begin{array}{l}\text { Number of } \\
\text { Respondent }\end{array}$} & \multicolumn{2}{|r|}{ Result } \\
\hline & & & Score & Persentage \\
\hline 1 & $\begin{array}{l}\text { The condition of the top (roof) of the building can } \\
\text { protect the safety of its inhabitants }\end{array}$ & 32 & 32 & $100 \%$ \\
\hline 2 & $\begin{array}{l}\text { The condition of the building walls can protect the } \\
\text { safety of its inhabitants }\end{array}$ & 32 & 32 & $100 \%$ \\
\hline 3 & $\begin{array}{l}\text { Conditions under the building (floor) can maintain the } \\
\text { safety of its inhabitants }\end{array}$ & 32 & 31 & $97 \%$ \\
\hline 4 & Lighting from the outside is sufficient & 32 & 31 & $97 \%$ \\
\hline 5 & Enough ventilation in the house & 32 & 30 & $94 \%$ \\
\hline 6 & Has its own latrine & 32 & 29 & $91 \%$ \\
\hline 7 & Has its own bathroom & 32 & 29 & $91 \%$ \\
\hline 8 & Has its own bedroom & 32 & 32 & $100 \%$ \\
\hline 9 & Has its own living room & 32 & 29 & $91 \%$ \\
\hline 10 & Space is sufficient & 32 & 29 & $91 \%$ \\
\hline \multicolumn{2}{|r|}{ Maximum of scores, total score and percentage score } & 320 & 275 & $86 \%$ \\
\hline
\end{tabular}

Source: processed data

Based on the results of the percentage of housing conditions after the program is $86 \%$ of the houses have met the criteria for livable homes, meaning that there was a $38 \%$ improvement in the quality of housing conditions from before the program after the program. $100 \%$ or all respondents have proper roofs and walls and can protect the safety of their residents after renovation, $97 \%$ or 31 of 32 respondents have a floor that can protect the safety of their inhabitants after renovation.

The condition of the house $97 \%$ of respondents after the program had adequate lighting coming into the house. 94\% have adequate ventilation in the house. $91 \%$ have their own latrines and bathrooms. $100 \%$ or all of the respondents have their own sleeping space. $91 \%$ have their own living room and 
home area after the program has provided enough space
The results of the analysis of the percentage of standards and policy objectives are:

Table 6. Results of Percentage Analysis of Standard Variables and Program Objectives

\begin{tabular}{lllll}
\hline No & Indicator & Maximum of scors & Total score & Persentage \\
\hline 1 & $\begin{array}{l}\text { Program Recipient Conformity } \\
\text { The condition of the house before the }\end{array}$ & 160 & 153 & $96 \%$ \\
2 & 320 & 153 & $48 \%$ \\
$\begin{array}{l}\text { program } \\
\text { The condition of the house after the }\end{array}$ & 320 & 275 & $86 \%$ \\
$\begin{array}{l}\text { program } \\
\text { Maximum number of scores, total score } \\
\text { and percentage score }\end{array}$ & 800 & 581 & $73 \%$
\end{tabular}

Source: processed data

The results of the percentage of standard variables and program targets is $73 \%$ so that it is categorized successful.

The success of the implementation of a policy program can be measured one of them with the standards and program targets that have been set, in implementing the Self-Help Housing Stimulant Assistance Program the standard and program targets have been regulated in Permen PURP No o7 / PRT / M / 2018 on Self-Help Housing Stimulant Assistance. so that the program implemented can be directed and can achieve the specified targets, according to Van Meter and Horn standards and policy program objectives must be clear and structured so that they can be realized, and according to Grandle in implementing a policy program success can be illustrated from the extent of changes that occur, and whether the location of a program is right. In this case the standards and targets of the BSPS Program in Desa Tempuran in 2018 are measured from 2 indicators namely the suitability of the program recipient, the condition of the house before the program and the condition of the house after the program

The results of the analysis of the percentage of standard and target variables are $73 \%$ so that they are categorized successful, and according to the results obtained are in accordance with the theories that have been mentioned. conducted by Hariani and Tuwis (2016) that the impact of the implementation of BSPS is the improvement of people's welfare. The implementation of BSPS in Desa Tempuran in 2018 had carried out the construction of new houses, but this was caused by damage to homes that were already severe so it was better to do new housing construction, as in research by Zulkarnain (2017) there were people who were doing new housing construction which whereas the provisions are only renovation of the house, but in the study by Zulkarnain due to lack of information from the facilitator.

\section{Institutional Capacity}

There are $\mathbf{2}$ indicators of the success of 
implementation in the institutional capacity variable, namely the suitability of the tasks and responsibilities of the beneficiaries and the suitability of the program implementation process.
The results of the analysis of the percentage of conformity of duties and responsibilities of beneficiaries are as follows:

Table 7. Results of Analysis of Assistance and Responsibility

Percentage of Assistance and Responsibility

\begin{tabular}{|c|c|c|c|c|}
\hline \multirow{2}{*}{ No } & \multirow{2}{*}{ Question } & \multirow[b]{2}{*}{ Number of Respondent } & \multicolumn{2}{|c|}{ Result } \\
\hline & & & Score & Persentage \\
\hline 1 & $\begin{array}{l}\mathrm{KPB} \text { is looking for a building shop } \\
\text { together }\end{array}$ & 32 & 32 & $100 \%$ \\
\hline 2 & $\begin{array}{l}\text { The KPB monitors the implementation } \\
\text { of development together with members } \\
\text { of the group receiving the assistance }\end{array}$ & 32 & 16 & $50 \%$ \\
\hline 3 & $\begin{array}{l}\text { KPB carried out the construction of } \\
\text { houses together in mutual cooperation }\end{array}$ & 32 & 4 & $13 \%$ \\
\hline 4 & $\begin{array}{l}\text { In the implementation of development, } \\
\text { the members of the KPB provide labor, } \\
\text { money or building materials to fellow } \\
\text { KPB members }\end{array}$ & 32 & 6 & $19 \%$ \\
\hline 5 & $\begin{array}{l}\text { In the implementation of development, } \\
\text { the members of the KPB get assistance } \\
\text { from workers, money or building } \\
\text { materials from fellow KPB members }\end{array}$ & 32 & 5 & $16 \%$ \\
\hline Tot & I score, total score and percentage score & 160 & 63 & $39 \%$ \\
\hline
\end{tabular}

Source: processed data

Based on the percentage of the suitability of the duties and responsibilities of the implementor in this case the recipient is $39 \%$. All respondents looked for building shops with their groups, in addition $50 \%$ or 16 out of 32 beneficiary respondents said that they monitored fellow beneficiary group members. The percentage number 3 was $13 \%$ meaning only 4 out of 32 respondents, percentage number 4 namely $19 \%$ or 6 of 32 from pesente number $516 \%$ or 5 of 32 respondents, based on the results of percentage numbers 3,4 and 5 ie less than $25 \%$ so that it can be concluded the lack of participation of beneficiary communities as fellow group members.

The results of the analysis of the suitability of the process of organizing the program are as follows: 
Table 8. Results of Analysis of the Suitability of Program Organizing Process

\begin{tabular}{|c|c|c|c|c|}
\hline \multirow{2}{*}{ No } & \multirow{2}{*}{ Question } & \multirow[b]{2}{*}{ Number of Respondent } & \multicolumn{2}{|c|}{ Result } \\
\hline & & & Score & Persentage \\
\hline 1 & $\begin{array}{l}\text { Information about the BSPS program } \\
\text { was carried out }\end{array}$ & 32 & 32 & $100 \%$ \\
\hline 2 & $\begin{array}{l}\text { Verification or survey when the } \\
\text { potential recipient of assistance is } \\
\text { conducted }\end{array}$ & 32 & 32 & $100 \%$ \\
\hline 3 & $\begin{array}{l}\text { An agreement was made with } \\
\text { prospective beneficiaries }\end{array}$ & 32 & 32 & $100 \%$ \\
\hline 4 & $\begin{array}{l}\text { Beneficiaries identified needs and } \\
\text { drafted a budget }\end{array}$ & 32 & 32 & $100 \%$ \\
\hline 5 & $\begin{array}{l}\text { The building shop delivers building } \\
\text { materials on time }\end{array}$ & 32 & 27 & $84 \%$ \\
\hline 6 & $\begin{array}{l}\text { Construction of beneficiary houses was } \\
\text { completed on time }\end{array}$ & 32 & 27 & $84 \%$ \\
\hline 7 & $\begin{array}{l}\text { Payment for the purchase of building } \\
\text { materials is carried out by the recipient } \\
\text { of assistance by way of transfer or } \\
\text { transfer of books to a building shop }\end{array}$ & 32 & 32 & $100 \%$ \\
\hline 8 & $\begin{array}{l}\text { Payment of the workers wages by cash } \\
\text { assistance }\end{array}$ & 32 & 32 & $100 \%$ \\
\hline 9 & Assistance is received in 2 stages & 32 & 32 & $100 \%$ \\
\hline 10 & $\begin{array}{l}\text { The second phase of assistance you } \\
\text { receive after construction reaches 30\% }\end{array}$ & 32 & 32 & $100 \%$ \\
\hline 11 & $\begin{array}{l}\text { The recipient of the assistance } \\
\text { prepares a report on the receipt of aid } \\
\text { stages } 1 \text { and } 2\end{array}$ & 32 & o & o\% \\
\hline Tota & score, total score and percentage score & 352 & 310 & $88 \%$ \\
\hline
\end{tabular}

Source: processed data

Based on the results of the percentage of suitability of the program implementation process that is $88 \%$ that the process that is carried out or carried out is very in accordance with predetermined rules, meaning that the characteristics of the implementor are compliant with the rules and regulations. All respondents with a percentage of $100 \%$ said that they had done socialization before the program, then also conducted verification and surveying, and identified the need for house renovation. $84 \%$ of respondents get a shipment of building materials on time and housing construction is also completed on time. 
All respondents with a percentage of $100 \%$ also make payments for building materials by way of transfer, pay workers' wages in cash and receive assistance in two phases where the second stage is received after construction has reached $30 \%$. It's just that the recipient of assistance is not able to prepare the report stages 1 and 2 due to the limited ability and understanding of the aid recipient, so that the preparation of the report is entirely carried out by Field Facilitator Staff (TFL).

The results of the analysis of institutional capacity variables are as follows:

Table 9. The Results of Percentage Analysis of Institutional Capacity Variables

\begin{tabular}{lllll}
\hline No & Indicator & Maximum of Score & Total Skor & Persentage \\
\hline 1 & $\begin{array}{l}\text { Suitability of Duties and Responsibilities } \\
\text { Suitability of Program Implementation }\end{array}$ & 160 & 63 & $39 \%$ \\
2 & 352 & 310 & $88 \%$ \\
$\begin{array}{l}\text { Process } \\
\text { Maximum score, total score and percentage }\end{array}$ & 512 & 373 & $73 \%$ \\
\hline
\end{tabular}

Source: processed data

The result of the percentage of institutional characteristic variables is $73 \%$ so it is categorized successful.

The institutional capacity of the program in this study was measured based on the suitability of the tasks and responsibilities of the implementor as well as the suitability of the BSPS implementation process. The suitability of the implementor's duties and responsibilities is from the recipient community. The suitability of the process of providing assistance is the process of organizing according to the BSPS technical guidelines for 2018. The result of the percentage of institutional characteristic variables is $73 \%$ so that it is categorized successful.

The beneficiaries are members of the BSPS Beneficiary Group (CDE) where there is a responsibility that self-help housing is realized as a result of the efforts of population groups to meet housing needs. Based on the table 4.5 the suitability of the duties and responsibilities of the implementor in this case is the recipient is $39 \%$. The community did not help each other or cooperate in the construction of their houses, statements from the beneficiary communities due to lack of manpower and time so that they focus on working on their own houses, besides the recipient communities also have hired artists individually which is also a new BSPS regulation which was implemented in 2018 , so 1 recipient hired 1 handyman

This also happened in several other previous studies such as the research conducted by Isabella, Julios Sesar, and Amaliatulwalidain (2014) in Way Serdang Subdistrict, Mesuji Regency, that there were human resource deficiencies because the community did not carry out mutual development. The new regulation adopted in 2018 has minimized obstacles in the implementation of the program so that in its implementation now there is no shortage of resources. 
The successful implementation of a program is inseparable from the support of good resources, and one of them is human resources, this research is not in accordance with the theory by Van Meter and Horn, namely the implementation of the program needs to be supported by both human and non-human resources. Human resource support includes skills and relationships between organizations or communication, the need for coordination and cooperation between agencies for the success of a program. Because even though it is seen from a low percentage, it means that the recipient community did not carry out the construction together or the self-help construction of the house continued to run smoothly because each beneficiary hired a handyman to finish his house, but the purpose of this program caused the self-help objectives of this program were not achieved.

The level of compliance of the implementor in carrying out the program is to carry out in accordance with specified regulations In implementing BSPS 2018, a regulation and guidelines for implementing the program have been determined, the implementor as the executor must follow the provisions that have been made. Based on the results of the percentage of suitability of the program implementation process that is $88 \%$ that the process that is carried out or carried out is very in accordance with predetermined rules, meaning that the characteristics of the implementor are compliant with the rules and regulations. It's just that the recipient of assistance is not able to prepare the report stages 1 and 2 due to the limited ability and understanding of the aid recipient, so that the preparation of the report is entirely carried out by Field Facilitator Staff (TFL). Characteristics of human resources or implementors also influence the success of program implementation as expressed in Grendle's theory, whether a policy has mentioned the implementor in detail and level of compliance, as well as the responsiveness of the target group, and this research is in accordance with the theory.

Different things happened in Zulkarnain's research (2016) The implementor was not compliant with the existing rules, the village technical team only pursued the benefits of sumplayer, so suppliers were reluctant to come to the BSPS location which resulted in the distribution of building materials belonging to the MBR to be not smooth.

\section{Financing}

There are 2 indicators of measuring the success of implementation in the financing variable, namely the distribution of aid funds to improve the quality of the house up to the hands of beneficiaries and the adequacy of funds according to community needs. The results of the analysis of the percentage of aid being distributed to the community are as follows: 
Tabel 1o. Results of Analysis of Percentage of Aid Distributed to Recipient's Hands

\begin{tabular}{|c|c|c|c|c|}
\hline \multirow{2}{*}{ No } & \multirow{2}{*}{ Question } & \multirow{2}{*}{$\begin{array}{l}\text { Number of } \\
\text { Respondent }\end{array}$} & \multicolumn{2}{|r|}{ Result } \\
\hline & & & Scor & Persentage \\
\hline 1 & $\begin{array}{l}\text { The recipient of the assistance received assistance to } \\
\text { improve the quality of the house by Rp. 15,0oo,ooo.oo }\end{array}$ & 32 & 32 & $100 \%$ \\
\hline 2 & $\begin{array}{l}\text { The help you receive is used to purchase building } \\
\text { materials and pay the workers' wages }\end{array}$ & 32 & 32 & $100 \%$ \\
\hline 3 & $\begin{array}{l}\text { Beneficiary communities receive building material and } \\
\text { cash assistance in stages } 1 \text { and } 2\end{array}$ & 32 & 32 & $100 \%$ \\
\hline \multicolumn{2}{|r|}{$\begin{array}{l}\text { Maximum number of scores, total score, and percentage } \\
\text { score }\end{array}$} & 96 & 96 & $100 \%$ \\
\hline
\end{tabular}

Source: processed data

Based on the percentage of funds distributed to aid recipients, it is known that the percentage results are $100 \%$, which means that BSPS funds from the central government of the PURP Ministry can be distributed well to all recipients in the form of building materials and cash and are used by beneficiary communities. in accordance with the provisions and procedures.

The results of the analysis of the percentage of adequacy of funds according to community needs are as follows:

Table 11.Results of Analysis of Fund Adequacy Percentage According to Community Needs

\begin{tabular}{|c|c|c|c|c|}
\hline \multirow{2}{*}{ No } & \multirow{2}{*}{ Question } & \multirow{2}{*}{$\begin{array}{l}\text { Number of } \\
\text { Respondent }\end{array}$} & \multicolumn{2}{|c|}{ Result } \\
\hline & & & Score & Persentage \\
\hline 1 & $\begin{array}{l}\text { Assistance received in accordance with the needs of } \\
\text { home renovation }\end{array}$ & 32 & 32 & $100 \%$ \\
\hline 2 & $\begin{array}{l}\text { There is a need for additional funds beyond assistance } \\
\text { to renovate the house }\end{array}$ & 32 & 27 & $84 \%$ \\
\hline 3 & Sufficient assistance & 32 & 10 & $31 \%$ \\
\hline \multicolumn{2}{|r|}{$\begin{array}{l}\text { Maximum number of scores, total score, and percentage } \\
\text { score }\end{array}$} & 96 & 69 & $72 \%$ \\
\hline
\end{tabular}

Source: processed data

Funds provided by the government of 15 million are not enough to renovate the house to completion because the funds provided are basically only stimulant funds, so the recipient community must prepare their own personal or self-help funds so that home renovations can be classified based on the results of a percentage of $72 \%$ of funds assistance can be said to be sufficient to renovate the respondent's house. All assistance was used by respondents for housing construction known to be $100 \%$. In Tempuran Village, it can be said that it was more successful to see that $84 \%$ or 27 of 32 respondents were almost able to finish their renovations well even though they spent additional funds on their own. $31 \%$ or 10 out of 32 respondents said that the funds were sufficient to build their houses. 
The results of the analysis of the percentage of financing variables are as follows:

Table 12. Results of Analysis of Percentage of Financing Variables

\begin{tabular}{llllll}
\hline No Indicator & & $\begin{array}{l}\text { Maximum } \\
\text { Score }\end{array}$ & Total skor & Pesentage \\
\hline 1 & $\begin{array}{l}\text { The distribution of assistance reaches the } \\
\text { recipient's hands }\end{array}$ & 96 & 96 & $100 \%$ \\
$2 \quad \begin{array}{l}\text { Adequacy of funds according to community needs } \\
\text { Maximum number of scores, total score, and } \\
\text { percentage score }\end{array}$ & & 192 & 165 & $72 \%$ \\
\hline
\end{tabular}

Source: processed data

Based on the results of the percentage of financing variables is $86 \%$ so it is categorized very successful.

The successful implementation of the program can also be influenced by funding, available and adequate financing and being used wisely will support the successful implementation of the program, in accordance with Van Meter and Horn's theory that implementation needs to support both human and non-human resources, and for nonhumans one of them is financing. The success of funding in the implementation of the BSPS program in Desa Tempuran is measured by 2 indicators, namely the distribution of aid to the hands of recipients and the adequacy of funds according to community needs.

Assistance received by the community in the BSPS program is assistance from the central government of the Ministry of PUPR, assistance provided is 15 million rupiahs with the type of assistance in the form of construction materials totaling $\mathbf{1 2 . 5}$ million rupees and cash to pay the wage rental of workers at 2.5 million rupiah, these funds are intended to renovate or improve the quality of the houses of the beneficiary from uninhabitable homes to livable homes. In accordance with Grandle's theory that the types of benefits received interfere with the successful implementation of the program. Based on the results of the percentage in table 4.10 is $86 \%$ so it is categorized that the financing variable in the implementation of the BSPS program in Desa Tempuran is very successful.

Based on the percentage of the distribution of funds to the recipient's hands is $100 \%$ means that the BSPS funds from the central government of the Ministry of PURP can be channeled properly to all recipients in the form of building materials and cash and as well as used by the beneficiary communities in accordance with the provisions and procedures. The same thing also happened in a study by Ratih Setyo Rini (2018) in West Kalimantan that the funds given to beneficiary communities could be used properly. But what happened was different in Zulkarnain's research (2017) in Parigi Selatan Sub-District, Parigi Moutong Regency. In his research, the reception of aid occurred unevenly and was not used wisely so that home renovations were not completed. 
Funds provided by the government in the amount of 15 million are not enough to renovate the house until completion, so the recipient community must prepare their own personal or self-help funds so that renovation of the house can be classified based on the results of a percentage of $72 \%$ of aid funds can be said to be sufficient to renovate the respondent's house. In Hariani and Tuwis's research (2016) in Sumber Rejo Village it was also revealed that the same thing happened where the recipient community spent additional self-help funds to renovate their houses, in their research many communities were not ready, so many beneficiary communities eventually lacked material and home renovation was not completed.

\section{Social and Political Conditions}

There are 2 indicators to measure the success of implementation in social and political conditions variables, namely the existence of support from resources from the community and the availability of support from interest groups.

The results of the percentage analysis of the support of resources from the community are as follows:

Table 13. Results of Analysis of Percentage of Community Resource Support

\begin{tabular}{|c|c|c|c|c|}
\hline \multirow{2}{*}{ No } & \multirow{2}{*}{ Question } & \multirow{2}{*}{$\begin{array}{l}\text { Number of } \\
\text { Respondent }\end{array}$} & \multicolumn{2}{|c|}{ Result } \\
\hline & & & Score & Persentage \\
\hline 1 & $\begin{array}{l}\text { Beneficiaries receive assistance in the form of } \\
\text { personnel from neighbors and relatives who are not } \\
\text { recipients of BSPS program assistance }\end{array}$ & 32 & 11 & $34 \%$ \\
\hline 2 & $\begin{array}{l}\text { Beneficiaries receive assistance in the form of money } \\
\text { from neighbors and relatives who are not recipients of } \\
\text { BSPS program assistance }\end{array}$ & 32 & 3 & $9 \%$ \\
\hline 3 & $\begin{array}{l}\text { Beneficiaries receive assistance in the form of building } \\
\text { materials from neighbors and relatives who are not } \\
\text { recipients of BSPS program assistance }\end{array}$ & 32 & 2 & $6 \%$ \\
\hline \multicolumn{2}{|r|}{$\begin{array}{l}\text { Maximum number of scores, total score and percentage } \\
\text { score }\end{array}$} & 96 & 16 & $17 \%$ \\
\hline
\end{tabular}

Source: processed data

Based on the analysis of the percentage of resource support from the community is $17 \%$ it can be said that the lack of support from the surrounding community for the implementation of the BSPS program. Only $34 \%, 11$ out of 32 respondents who received assistance from workers and relatives who were not recipients of the assistance. 9\% received financial assistance, 3 out of 32 respondents. And 6\% received aid in the form of building materials from people or community members who were not. The results of the percentage analysis of the existence of support from interest groups: 
Table 14. Results of Analysis of Percentage of Support from Interest Groups

\begin{tabular}{|c|c|c|c|c|}
\hline \multirow{2}{*}{ No } & \multirow{2}{*}{ Question } & \multirow{2}{*}{$\begin{array}{l}\text { Number of } \\
\text { Respondent }\end{array}$} & \multicolumn{2}{|c|}{ Resuly } \\
\hline & & & Score & Persentage \\
\hline 1 & $\begin{array}{l}\text { Results of Analysis of Percentage of Support from } \\
\text { Interest Groups }\end{array}$ & 32 & 31 & $97 \%$ \\
\hline 2 & $\begin{array}{l}\text { The village head is involved in overseeing the } \\
\text { implementation of the BSPS program }\end{array}$ & 32 & 29 & $91 \%$ \\
\hline 3 & $\begin{array}{l}\text { The village head is involved in implementing the BSPS } \\
\text { program }\end{array}$ & 32 & 9 & $28 \%$ \\
\hline \multicolumn{2}{|r|}{$\begin{array}{l}\text { Maximum number of scores, total score and percentage } \\
\text { score }\end{array}$} & 96 & 69 & $72 \%$ \\
\hline
\end{tabular}

Source: processed data

Based on the analysis of the percentage of support tables from interest groups in this case the support from the village head of the percentage is $72 \%$. The involvement of the village head in the BSPS preparation process was $97 \%$ of the statements of 31 of the 32 respondents meaning that the village head was very involved in the preparation of the BSPS
Program in Desa Tempuran. The involvement of village heads is $91 \%$ of the statements of 29 of the 23 respondents. And the involvement of the village head in the implementation was $28 \%$ of the statements of 9 of 32 respondents.

The results of the analysis of the percentage of social and political conditions variables are as follows:

Table 15. Results of Analysis of Variables on Social and Political Conditions Variables

\begin{tabular}{lllll}
\hline \multirow{2}{*}{ No } & Indicator & $\begin{array}{l}\text { Maximal } \\
\text { Score }\end{array}$ & Total skor & \multirow{2}{*}{ Persentage } \\
\hline 1 & There is support from community resources & 96 & 16 & $17 \%$ \\
2 & There is support from interest groups & 96 & 69 & $72 \%$ \\
\multicolumn{2}{l}{$\begin{array}{l}\text { Maximum number of scores, total score and percentage } \\
\text { score }\end{array}$} & 192 & 85 & $44 \%$ \\
\hline
\end{tabular}

Source: processed data

The results of the analysis of the percentage of social and political conditions is $44 \%$ so that it is quite successful.

Social and political conditions in the implementation of the BSPS program in Tempuran Village are measured by 2 indicators namely the presence of support from community resources and the support of interest groups. Basically, humans are social creatures, so in a social environment there is a relationship of mutual cooperation and mutual need. In this case social support is support from the surrounding community that is not included in the program recipient and the support from the interest groups here is from the village or kelurahan level government, namely the village head.

The result of the analysis of the percentage of social and political conditions was $44 \%$ so that it was categorized as quite 
successful, because despite the lack of support from the community, the village head continued to monitor the course of the program implementation process so that the BSPS program could be implemented well. Supporting social and political conditions in one region greatly influences the success of program implementation because it is possible that a program is declared to be successfully implemented in one area but fails to be implemented in another area due to the external conditions of the program which are less supportive. This has also been explained by Grandle in his theory that the policy environment or external environment such as the characteristics of institutions and regimes that are in power affect the implementation of the program. Social and political conditions affecting program implementation are also contained in the theory stated by Van Meter and Horn that the extent to which interest groups provide support, whether political elites support the implementation of policy programs and how the nature of public opinion in the environment.

As in Hariyani's research (2016) that this BSPS provides positive research from the community for the village head so that it will improve its image, which will have an impact on the support of residents when the village head will nominate again as village head in the next period. And the district government is very hopeful that the success of BSPS this year can provide an opportunity for the district to get BSPS assistance again the following year.

Different conditions occur in research conducted by Zulkarnain (2017) that in the research conducted at that time the sociopolitical conditions were not conducive so that the BSPS program that was implemented did not run well due to lack of coordination and communication between implementors so that the recipients of aid were lacking information.

\section{Implementation of BSPS in Desa Tempuran}

The results of the percentage of successful implementation of the BSPS Program in Desa Tempuran are as follows:

Table 16. Results of Analysis of the Percentage of Success of Implementation of BSPS in Desa Tempuran

\begin{tabular}{lllll}
\hline \multirow{2}{*}{ No } & \multicolumn{1}{c}{ Indicator } & $\begin{array}{l}\text { Maximal } \\
\text { Score }\end{array}$ & Total scre & Persentage \\
\hline 1 & Program Standards and Targets & 800 & 581 & $73 \%$ \\
2 & Institutional Capacity & 512 & 373 & $73 \%$ \\
3 & Financing & 192 & 165 & $86 \%$ \\
4 & Social and Political Conditions & 192 & 85 & $44 \%$ \\
\multicolumn{2}{l}{ Maximum scores, total score and percentage score } & 1696 & 1204 & $71 \%$ \\
\hline
\end{tabular}

Source: processed data

Based on the percentage results in table 4.15, the implementation of BSPS in Desa Tempuran is $71 \%$ so that the implementation of BSPS in Desa Tempuran is considered Successful.

\section{CONCLUSION}

Based on the descriptions that have been disclosed in the discussion, several conclusions can be drawn, namely: The results of the analysis of the percentage of standard variables and program targets are $73 \%$ so that they are categorized successful, this is supported by the magnitude of changes that occur from improving the quality of housing conditions from unfit to housing the house is livable, so that it can improve the welfare of the 
community, as well as the accuracy of the target recipient program.

The results of the analysis of the percentage of institutional characteristics variables are $73 \%$ so that they are categorized successful based on the tasks and responsibilities of the beneficiaries.

The results of the analysis of the percentage of financing variables is $86 \%$ so it is categorized that the financing variables in the implementation of the BSPS program in Tempuran Village were very successful. The whole assistance up to the recipient of the beneficiary and the wise use of aid by the beneficiary support the successful implementation of the program. Self-financing from beneficiary communities also supports the completion of the BSPS program.

The results of the analysis of the presentation of social and political conditions is that $44 \%$ can be categorized as quite successful, because despite the lack of support from the community, the village head continues to monitor the course of the program implementation process so that the BSPS program can be implemented well.

The results of the analysis of the percentage of successful implementation of BSPS in Tempuran Village, Bringin District, Semarang Regency from 4 variables namely program standards and targets, institutional capacity, financing, and social and political conditions are $70 \%$ so that they can be categorized as successful.

\section{REFERENCES}

Berliana, LA., Pujiati, Amin. (2017). Analysis of Wild Settlement Policy in the East Flood Canal. Economics Development Analysis Journal. Volume 3. Hal: 264- 272
BPS. (2018). Semarang Regency Regional Statistics. BPS: CV Pelita

Hariani dan Tuwis (2016). The Impact of the Implementation of Self-Help Housing Stimulant Assistance Programs to Increase Community Welfare. Equivalent Journal of Business Economics. Volume 2. No.2 Hal: 77-99

Inggriani. (2015). Evaluation of the Implementation of Self-Help Housing Stimulant Assistance Program (BSPS) in Dharmasraya Regency, West Sumatra JOM FISIP. Volume 2

Isabela., Sesar, Julio., \& Amaliatulwalidain. (2017). Evaluation of the Self-Help Housing Stimulant Assistance Program (Rejo Mulyo Village, Way Serdang District, Mesuji Regency, 2014). Journal of Government and Politics. Volume 2. No 1. Hal: 4144

Jian, Zuo., Bo, Xia., Jake, Barker., \& Martin, Skitmore. (2014). Green Buildings for Greying People: a Case Study of a Retirement Village In Australia. Facilities. Volume 32, Hal: 365-381

Juniarko, Oky., Surjono., Anwar, M. Ruslin. (2012). Evaluation of the Self-Help Housing Financing Stimulant Assistance System in Malang Regency. Journal of City and Regional Planning. Volume 4. Hal: 139-149

Nawawi, Ismail. (2009). Public Policy Strategy Analysis and Advocacy Theory and Practice. Surabaya: Putra Media Nusantara Surabaya

Nata, Inggriani., Manosso, H.,Mawikere, L M. (2018). Analysis of the Application of the Principles of Good Governance to the Self-Help Housing Stimulant Assistance Program at the Housing Agency for Settlement and Land Areas in North Halmahera Regency. Journal of Going Concern Accounting Research 13. Volome 3

Peraturan Menteri Pekerjaan Umum dan Perumahan Rakyat Republik Indonesia Nomor o7/ PRT/M Tahun 2018 About Self-help Stimulant Assistance

Priadi, Afisha R. (2018). Implementation of the Self-Help Housing Stimulant Assistance Program (BSPS) in the Provision of Livable Living in Langkat District. Skripsi. Medan: Universitas Sumatra Utara

Rini, Ratih Setyo. (2018). Supervision and Control of 2017 Ministry of Public Works Self-Help Housing Stimulant Assistance Activities in West Kalimantan Province.Cakrawala. Volume 18. Hal: $67-74$ 
Sahara, Sunni., dkk. (2012). Model Paket Pelayanan Penguasaan Konten Bertema Kesiapan Menikah Berbasis Multemedia pada Mahasiswa. Indonesian Journal of Guidance and Conseling Theory and Application.Volume 1. Hal: 64-70

Soesilowati, E. (2008) . Public Policy Theory and Application. Semarang: Universitas Negeri Semarang

Sugiyono. (2014). Quantitative, Qualitative, and R\&D Research Methods. Bandung: Alfabeta

Surat Edaran Kementrian PUPR Direktorat Jendral Penyediaan Perumahan Nomor o7/SE/Dr Tahun 2018 Regarding Technical Guidance for Providing Self-Help Housing Stimulant Assistance.

Undang- Undang Dasar Republik Indonesia year 1945 Pasal 28 About Human Rights
Undang-Undang Republik Indonesia Nomor 1 Tahun 2011 About Housing and Settlement Areas

Undang-Undang Republik Indonesia Nomor 4 Tahun 1992 About Housing and Settlements.

Wardani, Fatmawati NHK. (2010). About Housing and Settlements. Skripsi. Surakarta: Universitas Sebelas Maret.

Zhang, L, Zhao, S.X.B. and Tian, J.P. (2003). Self-Help in Housing and Chengzhongcun in China's Urbanisation. Internasional Journal of Urban and Regional Research. Volume 27.4. Hal: 912-937

Zulkarnain. (2017). mplementation of Self-Help Housing Stimulant Assistance Policy in South Parigi District. Asian Journal of Environment, History and Heritage. Volume 4. Hal: 179-188 